研究課題別研究評価

1. 研究課題名： 脳細胞の活動と形態変化の高速高分解能計測

2. 研究者名：藤崎久雄

\title{
3. 研究のねらい:
}

脳に関する観察・計測は樣々なレベルで行われている。医療の現場での X 線 CT , MRI, PET 等の 画像診断装置による生きている脳の内部観察，基礎研究における電子顕微鏡や共焦点レーザー走 査顕微鏡による切片試料の高分解能観察, 神経細胞の活動の電気生理学的な計測などの結果を 統合して脳の仕組みと働きに関する理解が進んでいる。本研究では，三次元的に複雑な構造の生物 試料の深部での生理学的事象を高速観察できるビデオレート 2 光子顕微鏡を構築し, 生きている脳 内の神経細胞および近傍の血流を高分解能で動態観察し，かつ活動の計測を同時に行う方法を確 立し，これによって脳内の細胞の形態と活動との関係を明らかにすることを目的とする。これらの研 究を通して得られる知識か脳の研究を推進させ，ひいては社会の高年齢化にともなって問題になっ ている脳の病気の解明が期待される。

\section{4. 研究結果及び自己評価 :}

1) 従来の方法によるラット脳の神経活動と血流の観察

麻酔下のラットの後脛骨神経を電気刺激し, クラニアル・ウインドウを設けた体性感覚領野において， 膜電位変化を蛍光色素法で, 局所血流変化をレーザードップラー血流計で, 血管の拡張・収縮 , 微 小血管内へモグロビンの総量およひ酸素化状態の変化を顕微分光分析システムで計測し, 燐光寿 命計測から毛細血管床内酸素分圧分布の変化を求めた。局所血流の調節が支配領域の上流で起 こっていることを示唆する結果を得た。(投稿準備中)

\section{2) 正立型ビデオレート 2 光子顕微鏡の構築}

ビデオレート共焦点顕微鏡 Nikon RCM8000 に正立の蛍光顕微鏡 Nikon E600FL を組み込み , フェ ムト秒パルス赤外レーザーSpectraphysics Tsunami を光源とすることによって正立型ビデオレート 2 光子顕微鏡を構築した。2 光子顕微鏡は共焦点光学系を介さずに光学切片が得られるため,ビデオ レート共焦点顕微鏡のスキャナーと画像取得の機能だけを使用した。随所で用いられるミラーは, 光 強度損失とミラ一損傷を避けるために, 近赤外での反射率の高いものを用いた。2 光子顕微鏡の一 つの特長は, 近赤外光を励起光とするために, 試料深部まで観察できることにある。とくに, 脳組織 のように光散乱が強い試料の観察では威力を発揮する。今回構筑した 2 光子顕微鏡では $300 \mathrm{~m}$ の深さにある毛細血管および神経細胞が観察できた。

3) 正立型ビデオレート 2 光子顕微鏡によるラット脳の神経活動と血流の観察

ラット脳内神経活動を観察するためにカルシウムイオン感受性蛍光色素 fluo3 AMで神経細胞を染 色し, 脳内の血流を観察するために蛍光色素 FITC て赤血球を染色して，1）と同樣の後脛骨神経電 気刺激を加えた。刺激に応答したカルシウムイオン濃度変化力観察された。毛細血管中の血流は必 要に応じで流れたり流れなかったりするという従来の説に反して，無束激下でも毛細血管の一部分を 観察し続けると，流速の変化，時には停滞，が見られた。刺激下では血流が上昇したが，1) での観 察と比べて，上昇率か高く，持続時間か短く，応答時間か涑激毎に異なった。これらの結果は，血流 制御が上流でなされ，毛細血管中では網目構造のゆえに部分部分で異なる応答をするが，局所（〜 $\left.1 \mathrm{~mm}^{3}\right)$ の平均/総和として一定の応答時間，一定の流量上昇を示すと解釈される。（主論文 : 投稿 準備中) 


\section{5. 領域総括の見解 :}

2 光子顕微鏡を開発して、細胞表層だけでなく $0.3 \mu \mathrm{m}$ 以上内部を可視化できるようにするプロジェ クトで、企業から離れて自由に発展させたいという目的であった。結果としては、確かに經組織で 0.3 $\mu \mathrm{m}$ 内層の毛細血管流力観察できたが、当初の目標から見て十分であったとは言い難い。この点は、 企業の技術者が大学の研究室で自らのプロジェクトを効率的に進めるやり方をあらかじめ考えておく ベきだったと反省する。

\section{6. 主な論文等 :}

藤崎久雄：「2光子励起蛍光顕微鏡」シリーズ・光力拓く生命科学 第7 巻『生命科学を拓く新しい光 技術』pp.122- 134 (共立出版, 1999).

藤崎久雄，佐甲靖志：「多光子励起顕微鏡と全反射顕微鏡によるバイオロジー」分光研究 48 , 260- 267 (1999)

藤崎久雄：「実験技術：2 光子顕微鏡」生物物理 40,195-198(2000)

藤崎久雄：「二光子励起法」実験医学別冊ザ・プロトコールシリーズ『GF とバイオイメージング一原 理・応用・検出のすべて』pp.191-196 (羊土社, 2000).

Hisao Fujisaki, Akitoshi Seiyama, Ichiro Sase, Yasuo Ooi, Junji Seki, Toshio Yanagida: "Loose coupling in neurovascular regulation during brain activation: An active regulation by bypass route in afferent vessel" (投稿準備中)

Hisao Fujisaki, Yasuo Ooi, Akitoshi Seiyama, Toshio Yanagida: "Inhomogeneous blood flow over the capillary network at the rat brain sensory area observed with a video-rate 2-photon microscope " (主論文 : 投稿準備中)

藤崎久雄, Gary Y. Fan, Rung-Kay Tsay, 宮脇敦史, R. Y. Tsien, M. H. Ellisman：「ビデオレート2光 子顕微鏡の開発と応用」第 22 回レーザ顕微鏡研究会講演会 (浜松; 静岡大学 1998.11)

藤崎久雄：「多光子励起レーザ一顕微鏡の特徵と生体計測法」岡崎国立共同研究機構 機構長招 聘三技術課合同セミナー (岡崎 ; 岡崎コンファレンスセンター 1998.12)

藤崎久雄 :「リアルタイム 2 光子顕微鏡の開発と応用, FRET の原理と応用など」第7回コンフォーカ ル 488 サマーシンポジウム (前橋; 国立赤城青年の家 1999.7)

藤崎久雄：「GFP FRET と 2 光子顕微鏡」電子顕微鏡学会シンポジウム (東京 北区; 北卜ピア 2000.5) 